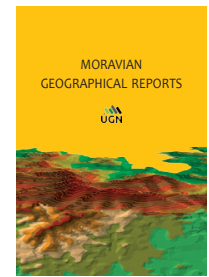

MORAVIAN GEOGRAPHICAL REPORTS

Institute of Geonics, The Czech Academy of Sciences

journal homepage: http://www.geonika.cz/mgr.html

doi: 10.2478/mgr-2019-0015

\title{
Modelling walking accessibility: A case study of Ljubljana, Slovenia
}

\author{
Jernej TIRAN ${ }^{\text {a }}$, Mitja LAKNER ${ }^{\text {b }}$, Samo DROBNE ${ }^{\text {b }}$
}

\begin{abstract}
Walkable access is recognised as one of the most important factors for deciding to walk instead of using other modes of transport. Distance has been less accurately taken into consideration in previous walking accessibility measures, however, as they are often based on an isotropic approach or on a fixed distance threshold. The objective of this paper is to present a method of modelling continuous walking accessibility to different amenities in a city, with an integrated network-based and distance-decay approach, applied to a case study of the city of Ljubljana, Slovenia. The approach is based on a web survey to obtain data on acceptable walking distances to different types of amenities. Several distance decay functions were analysed for each type of amenity from the cumulative frequency of responses. The best fitting functions were used to model the walking accessibility surfaces for individual amenities in the network, representing five domains (retail, services, recreation, education and transportation) and an overall walking accessibility index. Despite certain limitations and a further need to assess the validity of the methods, our distance-decay network-based approach is more accurate than the isotropic or even network-based modelling of walking distances in continuous or threshold approaches, as it enables the researcher to take into account the differences in propensities to walk to different amenities. The results can be used by city authorities and planners for implementing actions to improve walking accessibility in the most problematic areas.
\end{abstract}

Keywords: walking, walking accessibility, distance decay, spatial interaction model, network analysis, Ljubljana, Slovenia

Article history: Received 10 July 2019, Accepted 29 November 2019, Published 31 December 2019

\section{Introduction}

Defining walking accessibility to different amenities in an urban area is an important task for city authorities and urban planners when they analyse existing accessibility, or when they develop and design land use and the built environment of urban areas (Yigitcanlar et al., 2004). Although walkability measures usually take into account numerous factors, ranging from street connectivity, density, diversity of land use and destinations, route characteristics and safety, to aesthetic qualities (Cerin et al., 2007; Maghelal and Capp, 2011), it seems that distance has somehow been underestimated or at least less accurately taken into consideration in those measures. So far, only Walk Score (https://www.walkscore.com/), an internationally recognised web-based walkability assessment tool, has addressed this issue more precisely, using a distance-decay approach - but with certain drawbacks, such as not taking into account differences in trip purposes.
The aim of this paper is to present a GIS-based method of modelling walking accessibility to different types of amenities. The purpose of the method is to integrate network-based and distance-decay approaches of modelling walking accessibility, and to take into account the potential differences in the propensity to walk between different trip purposes.

The method has been applied to a case study of the city of Ljubljana, Slovenia, for which information about intra-urban walking accessibility is lacking. Without such information it is difficult to monitor the goal of urban sustainability to which the city is committed (Vision of Ljubljana 2025, 2019).

The paper is structured as follows. Section 2 reviews the literature on the walkability concept and methods to assess walking accessibility. Material and methods are described in Section 3, including survey data acquisition, modelling distance decay functions, walking accessibility

\footnotetext{
${ }^{a}$ Research Centre of the Slovenian Academy of Sciences and Arts, Ljubljana, Slovenia

${ }^{\mathrm{b}}$ Faculty of Civil and Geodetic Engineering, University of Ljubljana, Slovenia (*corresponding author: S. Drobne, e-mail: Samo.Drobne@fgg.uni-lj.si)
} 
surfaces and indices. In Section 4, the empirical results on propensities to walk, calibrated distance-decay functions, and walking accessibility indices are presented. This is followed by a discussion of the results in Section 5 and conclusions in Section 6 .

\section{Theoretical background}

The concept of walkability has been gaining increased attention by scholars, city authorities, social movements and initiatives, and urban planners in the last few decades. A walkable built environment has numerous positive effects on residents' well-being: it increases the number of walking trips (Cerin et al., 2007; Manaugh and El-Geneidy, 2011; Weinberger and Sweet, 2012) and thus enhances physical activity and health (Oishi et al., 2015; Rundle et al., 2016; Saelens et al., 2003); enhances life satisfaction (Cao, 2016; Jaśkiewicz and Besta, 2016, 2014); the level of social capital (Rogers et al., 2011); and residents' creativity (Oppezzo and Schwartz, 2014).

Among many walking needs, which range from feasibility to pleasurability (Alfonzo, 2005), good spatial accessibility from origins to destinations is found to be one of the most important, and it has been shown to influence the decision to walk over other transport modes (Boisjoly et al., 2018; Frank and Engelke, 2005; Giles-Corti et al., 2005; Giles-Corti and Donovan, 2002; Greenwald and Boarnet, 2001; Lund, 2003; Moudon et al., 2006; Owen et al., 2004; Reyer et al., 2014; Shriver, 1997). On the other hand, proximity is not necessarily the only factor (Giles-Corti et al., 2005) but can be secondary to individual and social environmental determinants (Giles-Corti and Donovan, 2002). In some cases, it is not even associated with walking (Cerin et al., 2007; Koohsari et al., 2013). Nevertheless, there has long been a general consensus that distance is an indispensable element of any type of accessibility (Hansen, 1959; Ingram, 1971), and walking accessibility is no exception in this regard (Forsyth, 2015).

With the widely-recognised importance of walkability for overall quality of urban life, there have been numerous attempts to develop methods and indices of walkability and walking accessibility, with objective GIS measures of the built environment being the most common (Brownson et al., 2009). It has been shown that objective measures have stronger associations with walking than subjective measures, such as self-reported perceptions of the environment (Hajna et al., 2013; Lin and Moudon, 2010). On the other hand, it is clear that objective measures have a high degree of variability (Brownson et al., 2009), and there is little agreement on theoretical and methodological assumptions for such measures (Cerin et al., 2007). Some scholars have urged the development of standardised measures of objective variables that can be replicated by other studies (Maghelal and Capp, 2011). Despite these limitations, GIS analyses can be widely used as a decision support tool for planning, enabling the rapid assessment of large areas (Ellis et al., 2016), or to understand the impact of the built environment on physical activities or modes of transportation (Lwin and Murayama, 2011; Tribby et al., 2015)

In the previous calculations of walkability scores, distance most often has been taken into consideration by using fixed distance thresholds, also called a pedestrian shed ratio (ped shed) or walkable catchment areas/buffers, mostly based on the concept of a reasonable walking distance (Frank et al., 2005; Kuzmyak et al., 2006; Lwin and Murayama, 2011; Porta and Renne, 2005; Witten et al., 2003). This method is very simple to use, but it has a number of drawbacks. Such measures are not necessarily based on precise findings of an acceptable, comfortable or desired walking distance, and they can mask within-buffer variations. Numerous studies have shown that the willingness to walk changes with distance (Iacono et al., 2010; Moudon et al., 2006; O'Sullivan and Morrall, 1996; Vasconcelos and Farias, 2012). At present, only Walk Score (https:/www.walkscore.com/) has addressed this issue more precisely - with a special polynomial distance decay function - but without referring to existing research and also ignoring the fact that the propensity to walk regarding distance might also differ by trip purpose, as numerous studies have shown (Larsen et al., 2010; O'Sullivan and Morrall, 1996; Shriver, 1997; Yang and Diez-Roux, 2012). A similar approach, but with a simplified version of distance bands, was used by Reyer et al. (2014).

Although walkability indices in general are found to be a reliable and valid measure of estimating access to walkable amenities (Carr et al., 2010; Duncan et al., 2011), and have also performed quite well in describing pedestrian behaviours (Manaugh and El-Geneidy, 2011; Stockton et al., 2016; Weinberger and Sweet, 2012) or vehicle miles travelled (Kuzmyak et al., 2006), they have conceptual and computational limitations, as Vale et al. (2015) argued in their extensive review of operational measures of active accessibility. For example, they can be less accurate in certain areas (Koschinsky et al., 2017), partly because they can mask within-buffer variations (Gutiérrez et al., 2011), or if they use Euclidean distance instead of the street network (Kozina, 2010).

One of the most important concepts in urban, regional and transport geography is the concept of distance decay. Many researchers of spatial interactions, starting from Ravenstein (1885) and Stewart (1948), have shown that the intensity of interactions in space depends significantly on the distance between the pairs of considered locations (Taylor and Openshaw, 1975). Waldo Tobler condensed the role of the distance for interactions in geographic space in the 'First Law of Geography' (Tobler, 1970, p. 236): "Everything is related to everything else, but near things are more related than distant things." The concept has often been applied in gravity-based models and spatial analyses (e.g. Cheng and Bertolini, 2013; Fotheringham and Pitts, 1995; Drobne and Lakner, 2014; Halás and Klapka, 2015; Martínez and Viegas, 2013; Tiefelsdorf, 2003; Timmermans et al., 2003). It has been used as well in walking accessibility studies, where it evaluates the effect of distance in the walking trips of individuals (Giles-Corti et al., 2005; Giles-Corti and Donovan, 2002; Gutiérrez et al., 2011; Yang and DiezRoux, 2012). Surprisingly perhaps, it has been employed very rarely for objective walkability and walk-score type measures in certain geographical areas. Among such measures, only the Walk Score has used this kind of approach to date - but with the above-mentioned limitations. A research question also remains: what is the best function of distance in gravity or potential models? In research to date, a cumulative Gaussian function has been considered as having the best fit for walking (Vale and Pereira, 2017).

\section{Materials and methods}

We suggest a network-based and distance-decay approach to modelling walking accessibility to different amenities in the urban environment in a geographical information systems (GIS) framework. The approach is applied to a case study of the city of Ljubljana: the largest city and the 
capital of Slovenia, with a population of 280,940 , an area of $163.8 \mathrm{~km}^{2}$ and a gross population density of $1,715.5$ people/ $\mathrm{km}^{2}$ (Statistical Office of the Republic of Slovenia, 2018). The rationale in selecting this particular city as a case study is manifold. The city is acknowledged for its central position within the Slovenian urban system (Nared et al., 2017), its high quality of urban life (Tiran, 2016), diverse urban morphology and urban land use (Tiran et al., 2016), also as sustainability-oriented, compact and green (Nastran and Green, 2016; Žlender and Ward-Thompson, 2017). The city is also known for its activities in improving conditions for walking, and signing the International Charter for Walking (https://www.walk21.com/charter). On the other hand, little is known about its (intra-urban) walking accessibility, which is one of the key determinants for choosing walking as a transport mode (Owen et al., 2004).

The research design phase of the project can be summarised as follows (see Fig. 1):

a. data acquisition on the propensity to walk to different amenities in Ljubljana by using a web survey;

b. analysis of the frequency distributions of responses, according to distance intervals in a spreadsheet; c. estimation of different distance decay functions for each type of amenity in software for technical calculations;

d. modelling the walking accessibility surfaces for each type of amenity by a network approach in GIS;

e. combining walking accessibility surfaces to obtain the overall walking accessibility surface in GIS;

f. analysis of the overall walking accessibility surface in GIS.

\subsection{Survey}

To obtain the subjective assessment of walking accessibility among Ljubljana residents, we conducted a web survey. The survey was performed between April and June 2014. The respondents were selected through non-probability sampling: the invitation and link to the survey was sent via a general invitation on mailing lists, forums and social media. A total of 663 respondents completed the survey. The sample was found to be representative regarding the demographic structure of the city population and its spatial distribution (according to area within the city), and dwelling type, with larger discrepancies only in a higher share of women and youth and a lower share of respondents living in single-family houses: see Table 1 . Among the items in the

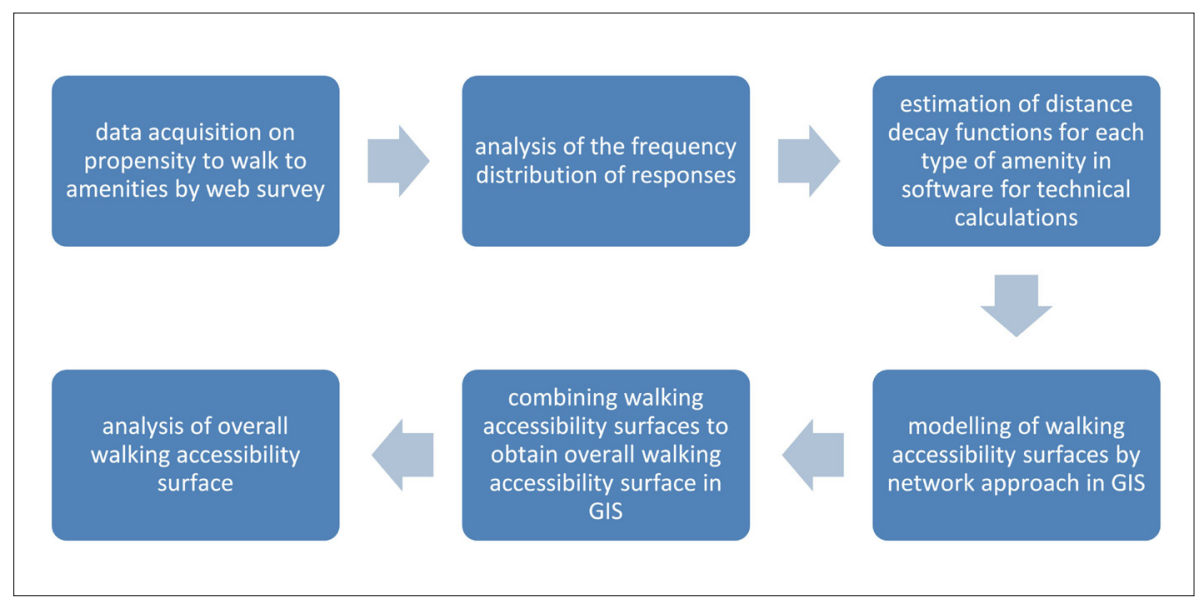

Fig. 1: Methodological steps used in the research design. Source: authors conceptualisation

\begin{tabular}{llcc}
\hline $\begin{array}{l}\text { Socio-demographic, dwelling type } \\
\text { and locational attributes }\end{array}$ & $\begin{array}{c}\text { Share of respondents } \\
(\%)\end{array}$ & $\begin{array}{c}\text { Actual share (\%) in city } \\
\text { population (2014) }\end{array}$ \\
\hline gender & male & 36.3 & 47.8 \\
& female & 63.7 & 52.2 \\
age & $15-35$ & 44.9 & 27.0 \\
& $36-45$ & 18.6 & 14.5 \\
& $46-55$ & 11.7 & 13.8 \\
& $56-65$ & 14.6 & 13.3 \\
dwelling type & single-family houses & 10.2 & 17.6 \\
& three- or more dwelling building & 27.9 & 41.4 \\
& multi-apartment building, tower block & 15.2 & 7.7 \\
\multirow{4}{*}{ location } & Bežigrad & 56.9 & 50.8 \\
& Center & 24.7 & 19.5 \\
& Moste & 18.4 & 9.0 \\
& Šiška & 14.4 & 25.9 \\
& Vič-Rudnik & 19.8 & 24.3 \\
\hline
\end{tabular}

Tab. 1: Demographic and geographic characteristics of the respondents, compared to city population Sources: authors' elaboration based on survey data 
survey, acceptability of the distance to amenities by foot was questioned (e.g. "What distance from your home to 'selected amenities', do you perceive as still acceptable for walking?"). The range of the responses followed the assumption that everybody is prepared to walk at least 1 minute, but no more than 30 minutes. Hence, the responses offered were: up to 1 minute; up to 3 minutes; up to 5 minutes; up to 10 minutes; up to 15 minutes; up to 20 minutes; and up to 30 minutes.

In order to reduce the survey burden, respondents had to answer for only five selected amenities, which they had previously selected as the most important in terms of walking accessibility from their apartment. Overall, they were choosing between 14 types of amenities: grocery store, hypermarket, pharmacy, community health centre, post office, ATM, urban green space, playground, sports ground, cultural amenity, restaurant, nursery school, primary school and bus stop.

To test the potential differences on the subjective assessments of walking accessibility between population groups, we carried out Kruskal-Wallis tests.

\subsection{Distance decay functions}

To estimate distance decay functions to the analysed amenities in Ljubljana, we constructed the frequency distribution of responses and calculated the proportion of respondents who are prepared to walk to a certain amenity at a certain distance, estimating a general propensity or willingness to walk to amenities in terms of distance. The results for cultural centres and restaurants were excluded from the analysis, as distance to the nearest one is of minor importance compared to their offer, which can be decisive for the usage of the rest of the amenities, so we cannot assume that people are using them solely because of proximity. Therefore, 12 types of amenities were analysed, and different distance decay functions were estimated for each type of amenity to assess the propensity to walk, and for other distances as well. The parameters of the functions, the goodness of fit, as well as walking accessibility for each type of amenity, were calculated and modelled in Mathematica 10.3.

The distance decay functions were constructed as xy coordinate graphs, where the $\mathrm{x}$ axis showed the maximum time (in minutes) from the origin to the destination (to the nearest amenity in the consideration), while the y axis gave the relative cumulative frequency (probability) of amenitydistance interactions.

For each $k$-dataset, we calculated four different distance decay functions that expressed the influence of time-distance to the propensity to walk. The tested set of functions were used and suggested by Martínez and Viegas (2013), Halás et al. (2014) and Halás and Klapka (2015); see functions (1-4) below:

1. normalised power-exponential function

$$
f(t)=\mathrm{e}^{-a t^{b}}, \quad a, b>0,
$$

2. Box-Cox's function

$$
f(t)=\mathrm{e}^{\frac{t^{a}-1}{a} b}, \quad a>0, \quad b<0,
$$

3. Tanner's function

$$
f(t)=t^{a} e^{b t}, a>0, b<0,
$$

\section{Richards' function}

$$
f(t)=c+\frac{a-c}{\left(1+d e^{-b(t-g)}\right)^{1 / h}}, \quad a, b, c, d, g \in \mathcal{R}, h>0
$$

All four analysed functions can be considered to be flexible functions because all have two or more parameters. However, the most flexible function is Richards' function that has four parameters and is able to capture analysed data in detail.

The procedure of estimating parameters $a, b, c, d, g, h$ was performed in Mathematica 10.3 using the least-square method, $\sum_{\mathrm{i}}\left(\mathrm{n}_{\mathrm{i}}^{\%}-\mathrm{f}(\mathrm{t})\right)^{2}=$ min. For each function and for each $k$-dataset, standard errors of estimation, $S E E$, were calculated. Coefficients of determination, $\mathrm{R}^{2}$, were calculated as $\mathrm{R}^{2}=1-\mathrm{SS}_{\text {res }} / \mathrm{SS}_{\text {tot }}$, where $\mathrm{SS}_{\text {res }}=\sum_{\mathrm{i}}\left(\mathrm{n}_{\mathrm{i}}^{\%}-\mathrm{f}(\mathrm{t})\right)^{2}$, $\mathrm{SS}_{\text {tot }}=\sum_{\mathrm{i}}\left(\mathrm{n}_{\mathrm{i}}^{\%}-\overline{\mathrm{n}}^{\%}\right)^{2}$ and $\overline{\mathrm{n}}^{\%}$ is the average value of the relative cumulative frequency of propensity to walk. The best-fitting function was used to model the walking accessibility in the network.

\subsection{Walking accessibility surfaces and indices}

For each type of amenity, a separate walking accessibility surface was modelled using the best-fitting function for each amenity and network paths. Walking accessibility surfaces were calculated by our own Python code in ArcGIS 10.3.

Geo-referenced amenities were extracted from available official sources. Network paths were imported from the OpenStreetMap web site and corrected by digital orthophoto images and with the field surveys. For conversion of the propensity to walk expressed in minutes to distances in metres, a walking speed of $4.8 \mathrm{~km} / \mathrm{h}$ (Transport for London, 2015) was selected. The walking accessibility surfaces for types of amenities were modelled by a 12.5-metre grid resolution

The overall walking accessibility index was calculated by combining partial walking accessibility surfaces. The indices of walking accessibility were combined within their respective domain:

- retail: grocery store, hypermarket;

- services: pharmacy, community health centre, post office, ATM;

- recreation: urban green space, playground, sports ground;

- education: nursery school, primary school; and

- transportation: bus stop.

For each domain, the walking accessibility surface for corresponding amenities was calculated as an average of the propensity to walk to corresponding amenities. This categorisation is an adapted version of the basic human functions concept, which was introduced by Partzsch (1964) and later adopted by the Munich school of social geography (Ruppert, 1984) and widely used to comprehend patterns of human mobility. The original concept also includes work and housing and does not separate retail from services. Other dimensions were added in the development of the concept, like living in the community and disposal. In this paper, the analysis was limited to those amenities that have also been recognised as important in other housing and residential well-being studies (Allen, 2015; Bonaiuto et al., 2003; Kyttä et al., 2016).

In the last step, the overall walking accessibility surface for all domains of amenities was calculated as an nonweighted average of the input domains' walking accessibility 
surfaces, multiplied by 100 . To compare the location of the amenities regarding their accessibility by foot with the spatial distribution of the population in the last step, we limited accessibility surfaces to the populated areas, defined with $100 \mathrm{~m}$ buffers around populated household addresses. For both aspects of the research - calculation of the overall walking accessibility surface, as well as its analysis according to the populated areas in the city of Ljubljana - the program ArcGIS 10.3 was used.

\section{Results}

\subsection{Propensity to walk}

Figure 2 shows the cumulative frequency of responses to walk to amenities at certain distances. It shows that the differences between amenities are the highest at 10 minutes. This can also be observed from the standard deviations in Table 2. At 3 minutes, the propensity to walk is still very high for all the amenities, while at 5 minutes, the differences start to increase and span from $95.8 \%$ (community health centre) to $67.0 \%$ (bus stop and playground). At 10 minutes, the range increases from $75.0 \%$ (primary school and community health centre) to $18.6 \%$ (bus stop). The profile then starts decreasing to very low differences at 30 minutes, where the propensity to walk to none of the amenities is over $5 \%$. In general, respondents are less willing to walk to the playground, bus stop, grocery store and ATM. On the other hand, the willingness is generally the highest for walking to primary school and the community health centre.

The calculated average decrease of the propensity to walk with increasing the distance shows that the decrease is not linear: it is largest between 5 and 15 minutes, when it decreases by $64.5 \%$ (see Tab. 3). For seven amenities (hypermarket, pharmacy, community health centre, post office, urban green space, nursery and primary school), the greatest decrease is between 5 and 10 minutes; and for five amenities (grocery store, ATM, playground, sports ground and bus stop) it is between 10 and 15 minutes. Those intervals are therefore the most "critical" with respect to the respondents' decision to walk or not with respect to distance. The second largest decrease is outside of any of those intervals for only 3 amenities: for the community health centre (25.3\% between 15 and 20 minutes), bus stop (26.9\% between 3 and 5 minutes), and playground (22.0\% between 3 and 5 minutes).

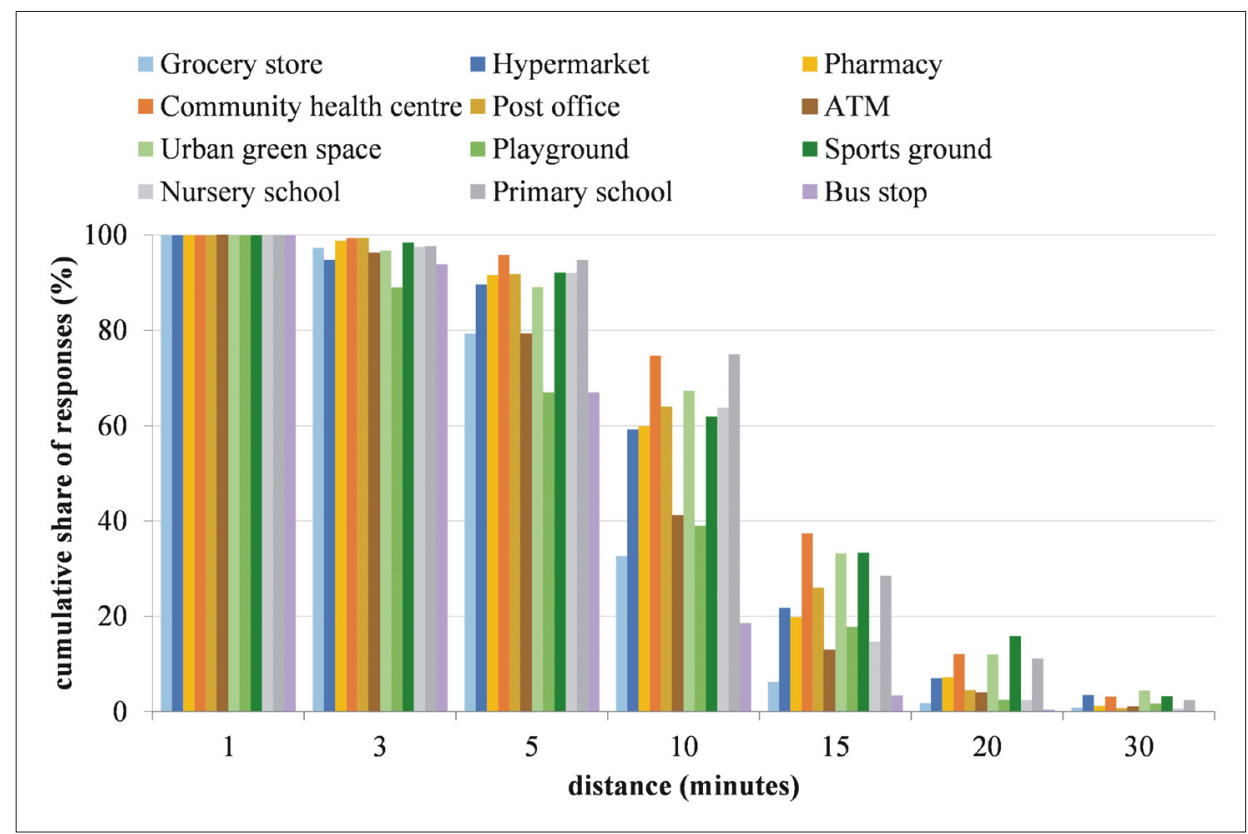

Fig. 2: Cumulative frequency of responses to walk to amenities Source: authors' calculations from survey data

\begin{tabular}{lrrrrrrr}
\hline $\begin{array}{c}\text { distance } \\
\text { (minutes) }\end{array}$ & $\mathbf{1}$ & $\mathbf{3}$ & $\mathbf{5}$ & $\mathbf{1 0}$ & $\mathbf{1 5}$ & $\mathbf{2 0}$ & $\mathbf{3 0}$ \\
\hline mean & 99.9 & 96.6 & 85.8 & 54.8 & 21.2 & 6.7 & 1.8 \\
standard deviation & 0.0 & 2.9 & 10.2 & 17.7 & 10.9 & 5.0 & 1.4 \\
\hline
\end{tabular}

Tab. 2: Standard deviation of the propensity to walk between amenities at certain distances Source: authors' survey

\begin{tabular}{ccccccc}
\hline $\begin{array}{c}\text { distances } \\
\text { (minutes) }\end{array}$ & $\mathbf{1}$ to $\mathbf{3}$ & $\mathbf{3}$ to $\mathbf{5}$ & $\mathbf{5}$ to $\mathbf{1 0}$ & $\mathbf{1 0}$ to $\mathbf{1 5}$ & $\mathbf{1 5}$ to $\mathbf{2 0}$ & $\mathbf{2 0}$ to $\mathbf{3 0}$ \\
\hline average decrease & 3.3 & 10.8 & 31.0 & 33.5 & 14.5 & 4.8 \\
\hline
\end{tabular}

Tab. 3: Average decrease of the propensity to walk to amenities between distances Source: authors' survey 
The Kruskal-Wallis tests revealed only some expected statistical differences between population groups. The propensity to walk (average of responses in minutes) is statistically different only for gender, age, dwelling type, and location and for certain amenities. The significant differences are noted as follows:

- Gender

- Urban green space $\left(\chi^{2}=11.319 ; d f=1 ; p=0.001\right)$

- Grocery store $\left(\chi^{2}=6.295 ; d f=1 ; p=0.012\right)$

- Post office $\left(\chi^{2}=5.748 ; d f=1 ; p=0.017\right)$

- Pharmacy $\left(\chi^{2}=4.680 ; d f=1 ; p=0.012\right)$

- Age

- Community health centre $\left(\chi^{2}=14.295 ; d f=4 ; p=0.006\right)$

- $\quad$ Post office $\left(\chi^{2}=9.988 ; d f=4 ; p=0.041\right)$

- Dwelling type

- $\quad$ Playground $\left(\chi^{2}=12.961 ; d f=2 ; p=0.002\right)$

- $\operatorname{Bus} \operatorname{stop}\left(\chi^{2}=11.039 ; d f=4 ; p=0.004\right)$

- Pharmacy $\left(\chi^{2}=6.475 ; d f=4 ; p=0.039\right)$

- Location

- Grocery store $\left(\chi^{2}=19.927 ; d f=; p=0.001\right)$

- $\operatorname{ATM}\left(\chi^{2}=13.340 ; d f=4 ; p=0.010\right)$

- $\operatorname{Bus} \operatorname{stop}\left(\chi^{2}=12.936 ; d f=4 ; p=0.012\right)$

- Post office $\left(\chi^{2}=10.456 ; d f=4 ; p=0.033\right)$

The results show that differences are statistically significant for post office ( $3 \times$, i.e. three times), bus stop $(2 \times)$, grocery store $(2 \times)$, pharmacy $(2 \times)$, ATM $(1 \times)$, urban green space $(1 \times)$, playground $(1 \times)$ and community health centre $(1 \times)$. Although statistically significant, the differences are very small in most cases. An interesting finding is that women are prepared to walk far more than men (e.g. 11.4 minutes versus 9.6 minutes to urban green space). On the other hand, propensity to walk does not differ for nursery school, primary school, hypermarket and sports ground for any of the population groups. Therefore, we decided not to correct the sample nor to use any additional weighting of responses due to the non-probability sampling. For the same reason we did not estimate distance decay functions for each population subgroup, treating them as a single population.

\subsection{Distance decay functions}

Table 4 shows the coefficients of determination $\left(R^{2}\right)$ for the analysed distance decay functions for the propensity to walk to the nearest amenity. Because the analysis was based on aggregated data (willingness to walk to specific amenity according to the classes of distance), all of the coefficients of determination for all analysed functions are very high. In spite of the fact that majority of the coefficients of determination for all analysed functions are very high and that the interpretation of Richards' function is difficult, we used Richards' function (4) for modelling purposes. For analysis purposes in general, however, it would be more convenient to use a simpler function with less parameters that gives comparable results (Halás and Klapka, 2015), e.g. the normalised power-exponential function (1). For these reasons, we show both results below. Tables 5 and 6 show the estimated parameters of the normalised power-exponential function (1) and, respectively, of Richards' function (4), for each type of amenity under consideration. A graphical representation of Richards' distance decay functions for different types of amenities is shown in Figure 3.

\subsection{Walking accessibility indices}

In Figures 4 and 5, the partial and final results of the modelling exercise are presented, which enabled us to make basic observations of the spatial distribution of amenities in the city. The results of the overall walking accessibility index indicate that the spatial distribution of the population fits very well with walking accessibility to amenities (see Fig. 6). If we interpret these data with the Walk Score classification, the majority (61.3\%) of Ljubljana residents live in a "very walkable" environment (index between 70 and 89), while only $18.4 \%$ live in a "car-dependent" environment (index of 49 or less). We can conclude that Ljubljana, in general, is a city with a solid walking accessibility of the residential areas, with as expected, the highest in the centre and the lowest in the outskirts.

Such a spatial pattern can be explained by four main factors. The first is the general adoption of the neighbourhood unit concept in urban planning, based on examples from Nordic countries in the period of the largest city growth from the 1960s to the 1980s. The concept also

\begin{tabular}{llcccc}
\hline $\mathbf{k}$ & Amenity & $\begin{array}{c}\text { normalised } \\
\text { power-exponential } \\
\text { function (1) }\end{array}$ & $\begin{array}{c}\text { Box-Cox's function } \\
(\mathbf{2})\end{array}$ & $\begin{array}{c}\text { Tanner's function } \\
\text { (3) }\end{array}$ & $\begin{array}{c}\text { Richards' function } \\
\mathbf{( 4 )}\end{array}$ \\
\hline 1 & Grocery store & 0.9986 & 0.9987 & 0.9568 & $\mathbf{0 . 9 9 9 0}$ \\
2 & Hypermarket & 0.9978 & 0.9977 & 0.9668 & $\mathbf{0 . 9 9 9 9}$ \\
3 & Pharmacy & 0.9985 & 0.9985 & 0.9667 & $\mathbf{0 . 9 9 9 6}$ \\
4 & Community health centre & 0.9990 & 0.9990 & 0.9639 & $\mathbf{0 . 9 9 9 9}$ \\
5 & Post office & $\mathbf{0 . 9 9 9 6}$ & 0.9996 & 0.9639 & 0.9994 \\
6 & ATM & 0.9985 & $\mathbf{0 . 9 9 8 8}$ & 0.9672 & 0.9987 \\
7 & Urban green space & 0.9973 & 0.9972 & 0.9705 & $\mathbf{0 . 9 9 9 8}$ \\
8 & Playground & 0.9945 & 0.9956 & 0.9698 & $\mathbf{0 . 9 9 6 2}$ \\
9 & Sports ground & 0.9980 & 0.9983 & 0.9808 & $\mathbf{0 . 9 9 9 8}$ \\
10 & Nursery school & 0.9983 & 0.9983 & 0.9490 & $\mathbf{0 . 9 9 9 9}$ \\
11 & Primary school & 0.9952 & 0.9952 & 0.9545 & $\mathbf{0 . 9 9 9 0}$ \\
12 & Bus stop & 0.9972 & 0.9976 & 0.9420 & $\mathbf{0 . 9 9 9 9}$ \\
\hline
\end{tabular}

Tab. 4: Coefficients of determination $\left(R^{2}\right)$ for distance decay functions for the propensity to walk to the nearest amenity (Notes: $k=1,2, \ldots, 12$ is the type of amenity under consideration; the bolded number denotes the row maximum)

Source: authors' elaboration from survey data 


\begin{tabular}{clcccc}
\hline $\mathbf{k}$ & Amenity & $\boldsymbol{S E E}$ & $\boldsymbol{R}^{2}$ & $\boldsymbol{a}$ & $\boldsymbol{b}$ \\
\hline 1 & Grocery store & 0.016 & 0.999 & 0.005 & 2.382 \\
2 & Hypermarket & 0.018 & 0.998 & 0.002 & 2.373 \\
3 & Pharmacy & 0.016 & 0.998 & 0.001 & 2.620 \\
4 & Community health centre & 0.013 & 0.999 & $4.2 \mathrm{E}-4$ & 2.851 \\
5 & Post office & 0.008 & 0.999 & 0.001 & 2.707 \\
6 & ATM & 0.016 & 0.998 & 0.008 & 2.062 \\
7 & Urban green space & 0.020 & 0.997 & 0.002 & 2.261 \\
8 & Playground & 0.028 & 0.995 & 0.028 & 1.549 \\
9 & Sports ground & 0.017 & 0.998 & 0.004 & 2.090 \\
10 & Nursery school & 0.017 & 0.998 & $2.3 \mathrm{E}-4$ & 3.312 \\
11 & Primary school & 0.028 & 0.995 & $3.1 \mathrm{E}-4$ & 3.023 \\
12 & Bus stop & 0.022 & 0.997 & 0.009 & 2.261 \\
\hline
\end{tabular}

Tab. 5: Parameters of normalised power-exponential distance decay function (1) for the propensity to walk to the nearest amenity in Ljubljana (Note: $f(t)=e^{\left(\left[t^{a}-1 / a\right] . b\right)} ; k=1,2, \ldots, 12$ is the type of amenity under consideration). Source: authors' elaboration

\begin{tabular}{|c|c|c|c|c|c|c|c|c|c|}
\hline $\mathbf{k}$ & Amenity & $S E E$ & $R^{2}$ & $a$ & $\boldsymbol{b}$ & $c$ & $d$ & $g$ & $h$ \\
\hline 1 & Grocery store & 0.013 & 0.999 & -0.002 & 0.294 & 1.012 & 0.002 & -1.452 & 0.001 \\
\hline 2 & Hypermarket & 0.003 & 0.999 & 0.035 & 0.383 & 1.065 & 3.663 & 9.059 & 1.629 \\
\hline 3 & Pharmacy & 0.009 & 0.999 & 0.018 & 0.335 & 1.023 & 6.438 & 4.162 & 0.761 \\
\hline 4 & Community health centre & 0.004 & 0.999 & 0.024 & 0.308 & 1.021 & 7.700 & 5.749 & 0.863 \\
\hline 5 & Post office & 0.010 & 0.999 & -0.001 & 0.352 & 1.064 & 15.490 & 5.026 & 1.397 \\
\hline 6 & ATM & 0.015 & 0.998 & 1.114 & -0.330 & 0.006 & 0.142 & 1.401 & 1.203 \\
\hline 7 & Urban green space & 0.006 & 0.999 & 0.043 & 0.357 & 1.119 & 9.387 & 8.939 & 2.304 \\
\hline 8 & Playground & 0.023 & 0.996 & 2.944 & -0.072 & 0.006 & 0.003 & 6.662 & 0.002 \\
\hline 9 & Sports ground & 0.006 & 0.999 & 0.009 & 0.181 & 1.013 & $2.8 \mathrm{E}-5$ & 1.232 & $5.9 \mathrm{E}-6$ \\
\hline 10 & Nursery school & 0.003 & 0.999 & 0.010 & 0.602 & 1.045 & 14.351 & 9.092 & 2.396 \\
\hline 11 & Primary school & 0.013 & 0.999 & 0.034 & 0.353 & 0.991 & 6.078 & 5.572 & 0.612 \\
\hline 12 & Bus stop & 0.005 & 0.999 & 1.004 & -1.453 & -0.008 & 0.078 & 1.799 & 5.570 \\
\hline
\end{tabular}

Tab. 6: Parameters of Richards' distance decay function (4) for the propensity to walk to the nearest amenity in Ljubljana (Note: $f(t)=c+(a-c) /\left(1+d e^{-b(t-g)}\right)^{1 / h} ; k=1,2, \ldots, 12$ is the type of amenity under consideration) Source: authors' elaboration

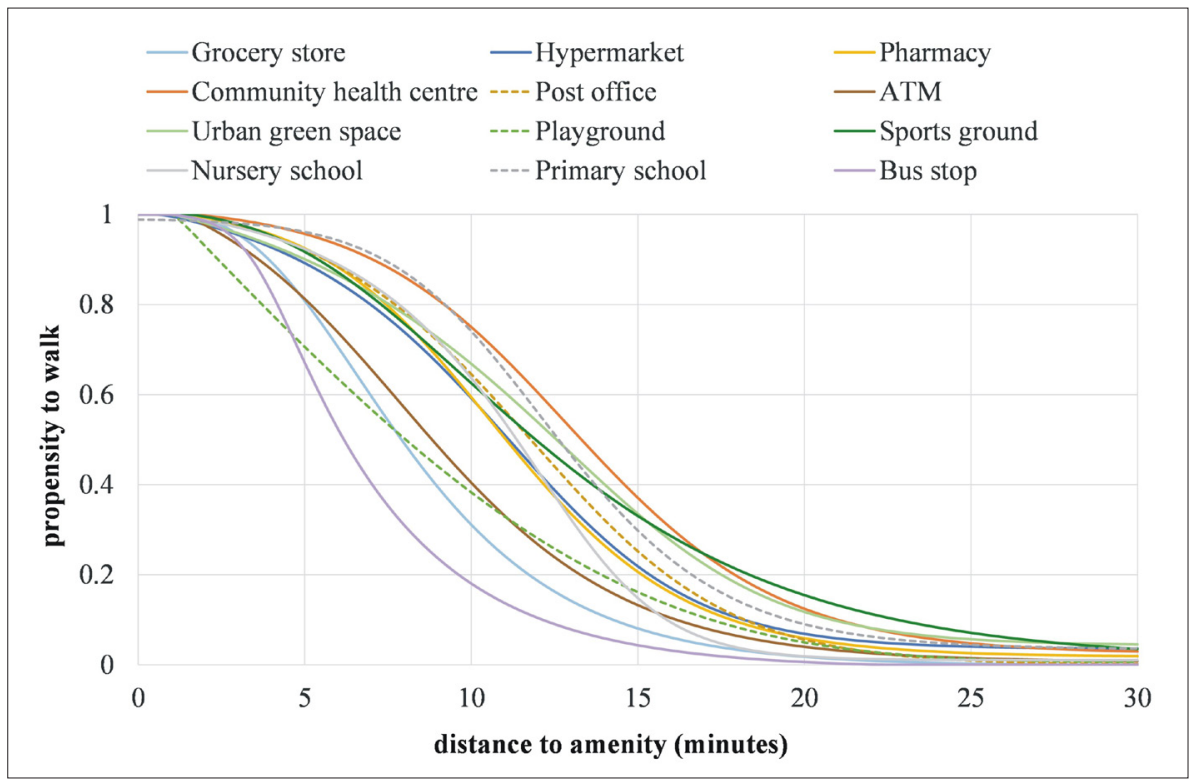

Fig. 3: Richards' distance decay functions for the propensity to walk to amenities in Ljubljana Source: authors' calculations 
emphasised the importance of locating the most important social infrastructure (grocery store, nursery school, primary school, playgrounds, bus stop) within the neighbourhood, including footpaths leading to them or locating the infrastructure at its edge within a walking distance, e.g. along the main artery road (Malešič, 2015). This explains the very high walking accessibility to most amenities in most of the city's territory: its centre and all main arteries along which most neighbourhoods with a majority of the population are located.

The second factor also relates to the urban planning system: in line with the concept of urban territorial cohesion and spatial justice, the spatial plans for Ljubljana have been supporting harmonious growth (Šašek Divjak, 2008), and the recent one also growth around the local centres (Municipality of Ljubljana, 2010). Consequently, those local centres are equipped with basic infrastructure, especially grocery stores, services and education facilities, providing good walking accessibility to them.

The third factor, which explains the dichotomy between centre and periphery, is the low population density and rural character of most of Ljubljana's outskirts. This is still very much visible in the built environment as the ground plan of former villages, which have been administratively merged into the town, remained almost intact (Tiran et al., 2016). There are very few urban amenities in those places, making

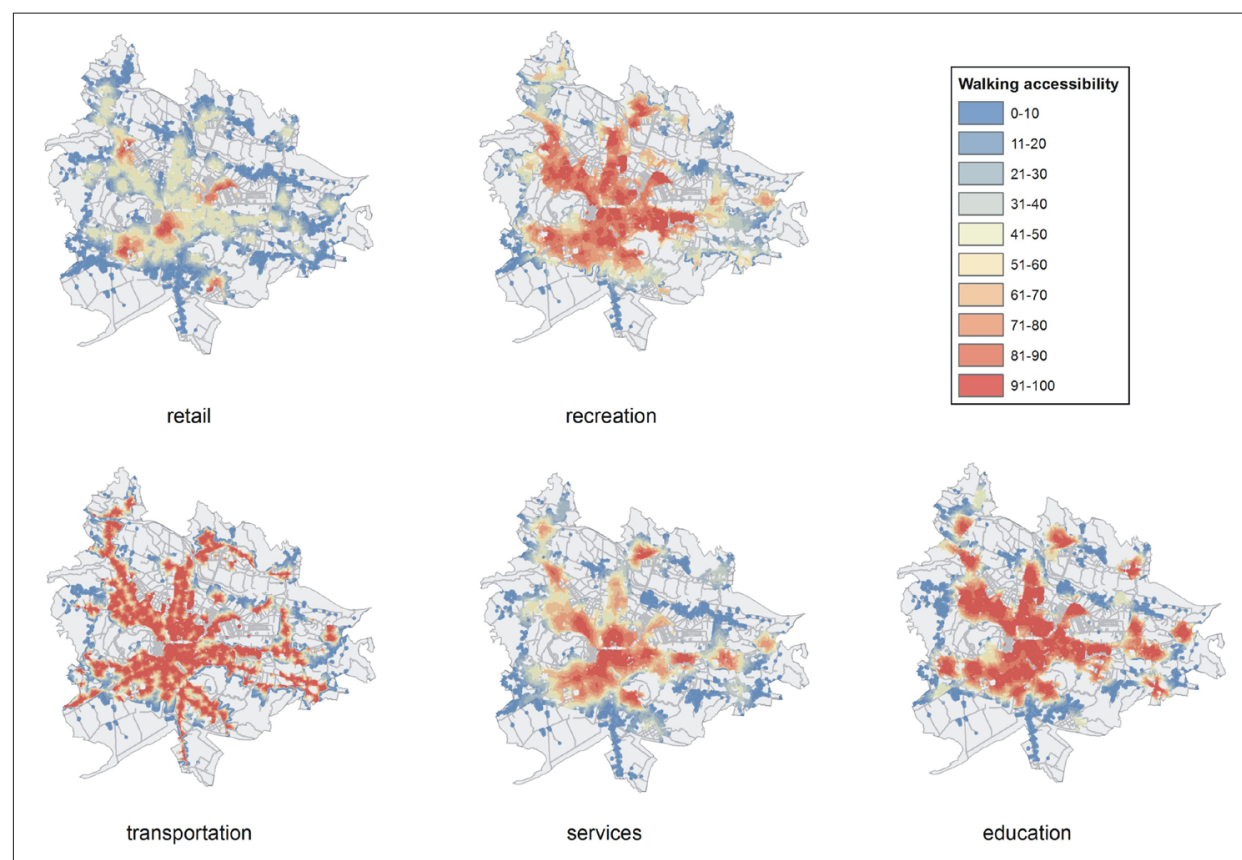

Fig. 4: Partial walking accessibility indices for each domain (retail, recreation, transportation, services, education) in the city of Ljubljana. Source: authors' calculations

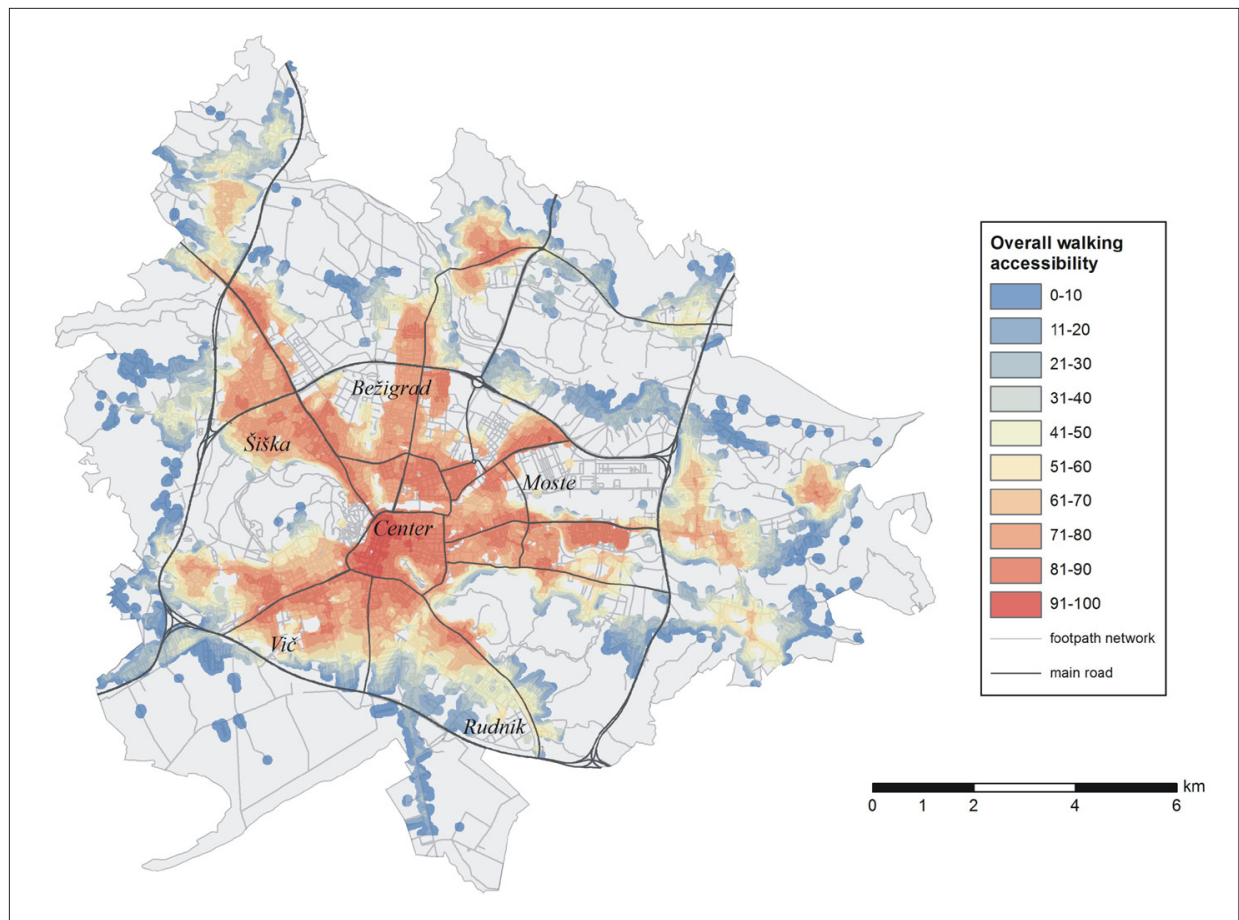

Fig. 5: Overall walking accessibility index in the city of Ljubljana.

Source: authors' calculations 
them almost non walkable and therefore car-dependent on the nearby local centres and shopping malls. The fourth factor also relates to the centre-periphery dichotomy. In the early 1990s in Ljubljana, spatial development was neglected because of prioritising macro-economic reforms at the national level. This led to the expansion of a dispersed or scattered residential and retail sprawl (Žlender and Ward Thompson, 2017), explaining the poorer walking accessibility on the outskirts.

\section{Discussion}

The main contribution of this paper is methodological in nature. The overall measure of accessibility can be described as a distance-based, location-based and gravitybased measure, calculated by the distance to the closest opportunity that integrates probabilistic methodology with the integration of a spatial interaction model, implemented in a GIS environment. The methodological approach applied here has numerous advantages over standard distance threshold methods. Firstly, being based on subjective assessments of walking distance makes this measure a better proxy of "real walking accessibility" than a rough estimation of walking distance, often used in measures of walkable access or in urban planning. Secondly, the method applies distance decay functions over the "standard" distance threshold approach, considering the fact that the propensity to walk changes over the distance in a non-linear manner. Thirdly, it takes into account the differences in the perceived walking distances between amenities, which we found to be significant. This is not an unexpected finding, as the trips to each amenity have their own specifics according to the frequency of visits, purpose, difficulty and other characteristics (e.g. waiting at the bus stop). Last but not least, the amenities are not weighted arbitrarily, such as for example in the Walk Score measure (despite claiming to refer to other studies), but rather groups them according to their respective functions to a human being. Although a more accurate weighting according to the importance of each amenity or frequency of visits was not applied, as in the study by Witten et al. (2003), this kind of approach probably better reflects the real needs of inhabitants rather than all amenities being treated equally.

We can also draw some theoretical contributions from the results of this study. One of them is that walking accessibility to the majority of amenities had the best fit with the Richards' function, which Martínez and Viegas (2013) also found suitable for accessibility assessment, especially for small distances. Our results also revealed that the largest decrease in propensity to walk is between 10 and 15 minutes (between 800 and 1,200 m) for most amenities, pointing to the distance band, where the use of a distance threshold is the most critical.

Nonetheless the methodology as presented also has its limitations. The survey was carried out using a nonrepresentative sample, so its results cannot be used to assess the willingness to walk for the entire population of Ljubljana. Additionally, it is based on the assumption that people tend to visit the closest amenity and it does not take into account the variety of options in the vicinity and some types of amenities where variety is superior to proximity (e.g. bars or restaurants). Neither does the measure consider attributes such as quality, equipment or assortment. For example, the frequency of bus arrivals can be a very important factor for using public transport instead of a car, or when choosing between bus stops. The same argument

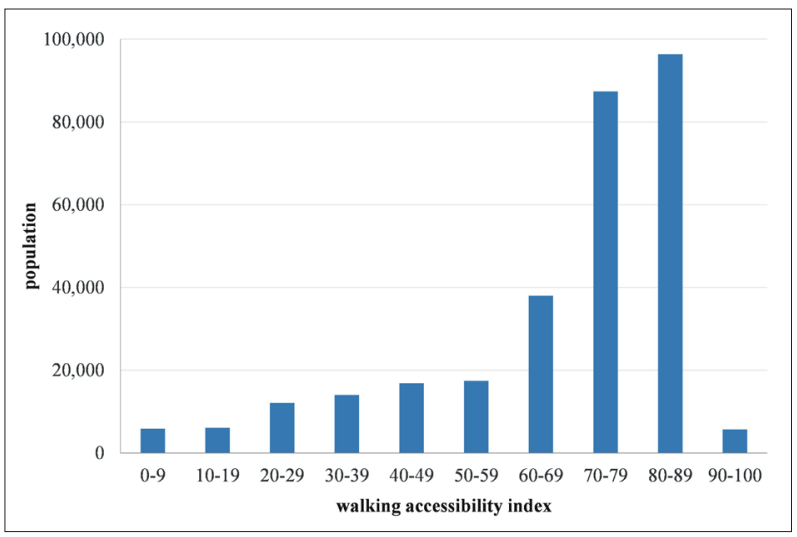

Fig. 6: Walking accessibility in the city of Ljubljana considering the distribution of the population

Source: authors' calculations

applies to urban green areas, which differ considerably in size, equipment, aesthetic features and maintenance. As the study by Giles-Corti et al. (2005) revealed, such factors can also have an influence on the choice of walking and choice of one amenity over another. In our approach, the selection of the amenities within each type and domain can strongly influence the results: this aspect of our research should be carefully taken into consideration in future studies adopting a similar methodology. The subjective assessment of respondents, based on which the distance decay parameters were constructed, may also be biased, but this element cannot be known.

Despite the careful formation of the questions, informats' responses and distance decay functions may not truly reflect their actual propensity to walk. As studies show, people can have a biased perception about the true length of certain trips (Button et al., 2016; Hernández and Witter, 2015; Krizek et al., 2012; Lowrey, 1970; Säisä et al., 1986). It is also possible that their answers simply do not reflect the real willingness to walk, especially among people who predominantly use other transport modes, or that people were estimating actual distances to frequently used amenities and not whether they are prepared to actually overcome a reported distance. The results are also less accurate due to the edge effect, as we calculated only accessibility to amenities inside the city boundaries, not taking into account the amenities in neighbouring settlements. Another limitation is that the approach does not consider the differences in personal characteristics (Manaugh and El-Geneidy, 2011; Reyer et al., 2014; Shriver, 1997) or personal attitudes (Lund, 2003), which have been shown to be significant. In our analysis, we used aggregate flow data instead of pair-wise data, an approach that raises the risk of over-smoothing the heterogeneity of the real urban pedestrian flows. To obtain more accurate results, agent-based modelling (Badland et al., 2013) or dynamic location-based accessibility modelling (Järv et al., 2018), should be carried out.

\section{Conclusions}

The method of measuring walking accessibility to amenities, as presented above and applied to the city of Ljubljana, is one of only a few attempts to integrate a network-based and distance-decay approach for objective walk-score type measures in a specific geographical area. It is more accurate than most widely-used methods using a 'distance threshold'. It is based on subjective assessments of 
walking distance, accounting for the fact that the propensity to walk does not decrease linearly with distance. Moreover, it takes into account differences in the propensity to walk to different amenities and groups amenities according to their respective functions. In addition, it is relatively easy to apply. Testing the validity of the proposed measures in comparison to actual pedestrian behaviours and other walkability indices is needed. Future developments of the method should derive distance-decay functions taking into account the importance of domains and types of amenities, as well as other elements that influence walking accessibility. Such a measure could then be widely used to estimate the share of walking, assess the quality of the residential environment and applied in urban planning as a strategic or practical tool for locating amenities, as well as for the site-development process. Such a process could help to increase the physical activity of people and thus residential well-being. Nevertheless, these results should already be useful for Ljubljana's city authorities and planners for implementing actions to improve walking accessibility in the most problematic areas.

\section{Acknowledgments}

The authors acknowledge the financial support from the Slovenian Research Agency research core funding Geography of Slovenia (P6-0101) and Earth observation and geoinformatics (P2-0406). Special thanks also to Jurij Velkavrh (University of Ljubljana, Faculty of Civil and Geodetic Engineering) and Jaka Ortar for the technical support on calculations in GIS.

\section{References:}

ALFONZO, M. A. (2005): To Walk or Not to Walk? The Hierarchy of Walking Needs. Environment and Behavior, 37(6): 808-836.

ALLEN, N. (2015): Understanding the Importance of Urban Amenities: A Case Study from Auckland. Buildings, 5(1): 85-99.

BADLAND, H., WHITE, M., MACAULAY, G., EAGLESON, S. MAVOA, S., PETTIT, C., GILES-CORTI, B. (2013): Using simple agent-based modeling to inform and enhance neighborhood walkability. International Journal of Health Geographics, 12(1): 58.

BOISJOLY, G., WASFI, R., EL-GENEIDY, A. (2018): How much is enough? Assessing the influence of neighborhood walkability on undertaking 10-minutes walks. Journal of Transport and Land Use, 11(1): 143-151.

BONAIUTO, M., FORNARA, F., BONNES, M. (2003): Indexes of perceived residential environment quality and neighbourhood attachment in urban environments: a confirmation study on the city of Rome. Landscape and Urban Planning, 65(1): 41-52.

BROWNSON, R. C., HOEHNER, C. M., DAY, K., FORSYTH, A., SALLIS, J. F. (2009): Measuring the Built Environment for Physical Activity. American Journal of Preventive Medicine, 36(4): S99-S123.e12.

BUTTON, C., SCHOFIELD, M., CROFT, J. (2016): Distance perception in an open water environment: Analysis of individual differences. Attention, Perception, \& Psychophysics, 78(3): 915-922.

CAO, X. (Jason) (2016): How does neighborhood design affect life satisfaction? Evidence from Twin Cities. Travel Behaviour and Society, 5: 68-76.
CARR, L. J., DUNSIGER, S. I., MARCUS, B. H. (2010): Validation of Walk Score for estimating access to walkable amenities. British Journal of Sports Medicine, 45(14): 1144-1148.

CERIN, E., LESLIE, E., OWEN, N., BAUMAN, A. E. (2007): Applying GIS in physical activity research: Community 'walkability' and walking behaviors. In: GIS for Health and the Environment (pp. 72-89). Dordrecht, Springer.

CHENG, J., BERTOLINI, L. (2013): Measuring urban job accessibility with distance decay, competition and diversity. Journal of Transport Geography, 30: 100-109.

DROBNE, S., LAKNER, M. (2014): Which distance-decay function for migration and which one for commuting?: the case study of Slovenia. Croatian operational research review, 5(2): 259-272.

DUNCAN, D. T., ALDSTADT, J., WHALEN, J., MELLY, S. J., GORTMAKER, S. L. (2011): Validation of Walk Score ${ }^{\circledR}$ for Estimating Neighborhood Walkability: An Analysis of Four US Metropolitan Areas. International Journal of Environmental Research and Public Health, 8(11): 4160-4179.

ELLIS, G., HUNTER, R., TULLY, M. A., DONNELLY, M., KELLEHER, L., KEE, F. (2016): Connectivity and physical activity: using footpath networks to measure the walkability of built environments. Environment and Planning B: Planning and Design, 43(1): 130-151.

FORSYTH, A. (2015): What is a walkable place? The walkability debate in urban design. Urban design international, 20(4): 274-292.

FOTHERINGHAM, A. S., PITTS, T. C. (1995): Directional Variation in Distance Decay. Environment and Planning A, 27(5): 715-729.

FRANK, L. D., ENGELKE, P. (2005): Multiple Impacts of the Built Environment on Public Health: Walkable Places and the Exposure to Air Pollution. International Regional Science Review, 28(2): 193-216.

FRANK, L. D., SCHMID, T. L., SALLIS, J. F., CHAPMAN, J., SAELENS, B. E. (2005): Linking objectively measured physical activity with objectively measured urban form: Findings from SMARTRAQ. American Journal of Preventive Medicine, 28(2, Supplement 2): 117-125.

GILES-CORTI, B., BROOMHALL, M. H., KNUIMAN, M., COLlins, C., DOUGLAS, K., Ng, K., LANGE, A., DONOVAN, R. J. (2005): Increasing walking. How Important is Distance to, Attractiveness, and Size of Public Open Space? American Journal of Preventive Medicine, 28(2): 169-176.

GILES-CORTI, B., DONOVAN, R. J. (2002): The relative influence of individual, social and physical environment determinants of physical activity. Social Science \& Medicine, 54(12): 1793-1812.

GREENWALD, M., BOARNET, M. (2001): Built Environment as Determinant of Walking Behavior: Analyzing Nonwork Pedestrian Travel in Portland, Oregon. Transportation Research Record: Journal of the Transportation Research Board, 1780(1): 33-41.

GUTIÉRREZ, J., CARDOZO, O. D., GARCÍAPALOMARES, J. C. (2011): Transit ridership forecasting at station level: an approach based on distance-decay 
weighted regression. Journal of Transport Geography, 19(6): 1081-1092.

HAJNA, S., DASGUPTA, K., HALPARIN, M., ROSS, N. A. (2013): Neighborhood Walkability. American Journal of Preventive Medicine, 44(6): e55-e59.

HALÁS, M., KLAPKA, P., KLADIVO, P. (2014): Distancedecay functions for daily travel-to-work flows. Journal of Transport Geography, 35: 107-119.

HALÁS, M., KLAPKA, P. (2015): Spatial influence of regional centres of Slovakia: analysis based on the distance-decay function. Rendiconti Lincei. Scienze Fisiche e Naturali, 26(2): 169-185.

HANSEN, W. G. (1959): How Accessibility Shapes Land Use. Journal of the American Institute of Planners, 25(2): 73-76.

HERNÁNDEZ, D., WITTER, R. (2015): Perceived vs. Actual Distance to Transit in Santiago, Chile. Journal of Public Transportation, 18(4): 16-30.

IACONO, M., KRIZEK, K. J., EL-GENEIDY, A. (2010): Measuring non-motorized accessibility: issues, alternatives, and execution. Journal of Transport Geography, 18(1): 133-140.

INGRAM, D. R. (1971): The concept of accessibility: A search for an operational form. Regional Studies, 5(2): 101-107.

JAŚKIEWICZ, M., BESTA, T. (2014): Is Easy Access Related to Better Life? Walkability and Overlapping of Personal and Communal Identity as Predictors of Quality of Life. Applied Research in Quality of Life, 9(3): 505-516.

JÄRV, O., TENKANEN, H., SALONEN, M., AHAS, R., TOIVONEN, T. (2018): Dynamic cities: location-based accessibility modelling as a function of time. Applied geography, 95: 101-110.

JAŚKIEWICZ, M., BESTA, T. (2016): Polish Version of the Neighbourhood Environment Walkability Scale (NEWSPoland): International Journal of Environmental Research and Public Health, 13(11): 1090.

KOOHSARI, M. J., KACZYNSKI, A. T., GILES-CORTI, B., KARAKIEWICZ, J. A. (2013): Effects of access to public open spaces on walking: Is proximity enough? Landscape and Urban Planning, 117: 92-99.

KOSCHINSKY, J., TALEN, E., ALFONZO, M., LEE, S. (2017): How walkable is Walker's paradise? Environment and Planning B: Urban Analytics and City Science, 44(2): 343-363.

KOZINA, J. (2010): Modeliranje prostorske dostopnosti do postajališč javnega potniškega prometa $\mathrm{v}$ Ljubljani. Geografski Vestnik, 82(1): 97-107.

KRIZEK, K., HORNING, J., EL-GENEIDY, A. (2012): Perceptions of accessibility to neighbourhood retail and other public services. Accessibility and Transport Planning: Challenges for Europe and North America, 96-117.

KUZMYAK, J., BABER, C., SAVORY, D. (2006): Use of walk opportunities index to quantify local accessibility. Transportation Research Record: Journal of the Transportation Research Board, 1977(1): 145-153.

KYTTÄ, M., BROBERG, A., HAYBATOLLAHI, M., SCHMIDT-THOME, K. (2016): Urban happiness: context-sensitive study of the social sustainability of urban settings. Environment and Planning B: Planning and Design, 43(1): 34-57.

LARSEN, J., EL-GENEIDY, A., YASMIN, F. (2010): Beyond the quarter mile: re-examining travel distances by active transportation. Canadian Journal of Urban Research, 19(1): 70 .

LIN, L., MOUDON, A. V. (2010): Objective versus subjective measures of the built environment, which are most effective in capturing associations with walking? Health \& Place, 16(2): 339-348.

LOWREY, R.A. (1970): Distance Concepts of Urban Residents. Environment and Behavior, 2(1): 52-73.

LUND, H. (2003): Testing the Claims of New Urbanism: Local Access, Pedestrian Travel, and Neighboring Behaviors. Journal of the American Planning Association, 69(4): 414-429.

LWIN, K. K., MURAYAMA, Y. (2011): Modelling of urban green space walkability: Eco-friendly walk score calculator. Computers, Environment and Urban Systems, 35(5): 408-420.

MAGHELAL, P. K., CAPP, C. J. (2011): Walkability: A Review of Existing Pedestrian Indices. Journal of the Urban \& Regional Information Systems Association, 23(2): 5-19.

MALEŠIČ, M. (2015): Nastanek in rast ljubljanskih stanovanjskih sosesk. AB. Arhitektov bilten, 45: 63-66.

MANAUGH, K., EL-GENEIDY, A. (2011): Validating walkability indices: How do different households respond to the walkability of their neighborhood? Transportation Research Part D: Transport and Environment, 16(4): 309-315.

MARTÍNEZ, L. M., VIEGAS, J. M. (2013): A new approach to modelling distance-decay functions for accessibility assessment in transport studies. Journal of Transport Geography, 26: 87-96.

MOUDON, A. V., LEE, C., CHEADLE, A. D., GARVIN, C., JOHNSON, D., SCHMID, T. L., LIN, L. (2006): Operational definitions of walkable neighborhood: theoretical and empirical insights. Journal of Physical Activity and Health, 3(1): 99-117.

MUNICIPALITY OF LJUBLJANA (2010): Municipal Spatial Plan - The Strategic Part [online]. [cit. 11.11.2019]. Available at: https://www.ljubljana.si/assets/OPNMOL/2010-78-4263-NPB9.pdf

NARED, J., BOLE, D., VALJAVEC, M. B., CIGLIČ, R., GOLUŽA, M., KOZINA, J., VISKOVIĆ, N. R., REPOLUSK, P., RUS, P., TIRAN, J. AND ISTENIČ, M. Č. (2017): Central settlements in Slovenia in 2016. Acta geographica Slovenica, 57(2): 7-32.

NASTRAN, M., REGINA, H. (2016): Advancing urban ecosystem governance in Ljubljana. Environmental science \& policy, 62: 123-126.

OISHI, S., SAEKI, M., AXT, J. (2015): Are People Living in Walkable Areas Healthier and More Satisfied with Life? Applied Psychology: Health and Well-Being, 7(3): 365-386.

OPPEZZO, M., SCHWARTZ, D. L. (2014): Give your ideas some legs: The positive effect of walking on creative 
thinking. Journal of Experimental Psychology: Learning, Memory, and Cognition, 40(4): 1142-1152.

OWEN, N., HUMPEL, N., LESLIE, E., BAUMAN, A., SALLIS, J. F. (2004): Understanding environmental influences on walking: review and research agenda. American journal of preventive medicine, 27(1): 67-76.

O'SULLIVAN, S., MORRALL, J. (1996): Walking distances to and from light-rail transit stations. Transportation Research Record: Journal of the Transportation Research Board, 1538(1): 19-26.

PARTZSCH,D. (1964):ZumBegriffder Funktionsgesellschaft. Mitteilungen Des Deutschen Verbandes Für Wohnungswesen, Städtebau Und Raumplanung, 4: 3-10.

PORTA, S., RENNE, J. L. (2005): Linking urban design to sustainability: formal indicators of social urban sustainability field research in Perth, Western Australia. URBAN DESIGN International, 10(1): 51-64.

RAVENSTEIN, E. G. (1885): The Laws of Migration. Journal of the Statistical Society of London, 48(2): 167-235.

REYER, M., FINA, S., SIEDENTOP, S., SCHLICHT, W. (2014): Walkability is Only Part of the Story: Walking for Transportation in Stuttgart, Germany. International Journal of Environmental Research and Public Health, 11(6): 5849-5865.

RICHARDS, F. J. (1959): A flexible growth function for empirical use. Journal of Experimental Botany, 10(2): 290-301.

ROGERS, S. H., HALSTEAD, J. M., GARDNER, K. H., CARLSON, C. H. (2011): Examining Walkability and Social Capital as Indicators of Quality of Life at the Municipal and Neighborhood Scales. Applied Research in Quality of Life, 6(2): 201-213.

RUNDLE, A. G., SHEEHAN, D. M., QUINN, J.W., BARTLEY, K., EISENHOWER, D., BADER, M. M. D., LOVASI, G. S.,NECKERMAN, K. M. (2016): Using GPS Data to Study Neighborhood Walkability and Physical Activity. American Journal of Preventive Medicine, 50(3): e65-e72.

RUNDLE, A., ROUX, A. V. D., FREEMAN, L. M., MILLER, D., NECKERMAN, K. M., WEISS, C. C. (2007): The Urban Built Environment and Obesity in New York City: A Multilevel Analysis. American Journal of Health Promotion, 21(4_suppl): 326-334. https://doi. org/10.4278/0890-1171-21.4s.326

RUPPERT, K. (1984): The concept of social geography. GeoJournal, 9(3): 255-260.

SAELENS, B. E., SALLIS, J. F., BLACK, J. B., CHEN, D. (2003): Neighborhood-Based Differences in Physical Activity: An Environment Scale Evaluation. American Journal of Public Health, 93(9): 1552-1558.

SÄISÄ, J., SVENSSON-GÄRLING, A., GÄRLING, T., LINDBERG, E. (1986): Intraurban Cognitive Distance: The Relationship between Judgments of StraightLine Distances, Travel Distances, and Travel Times. Geographical Analysis, 18(2): 167-174.

SHRIVER, K. (1997): Influence of Environmental Design on Pedestrian Travel Behavior in Four Austin Neighborhoods. Transportation Research Record: Journal of the Transportation Research Board, 1578(1): 64-75.
STEWART, J. Q. (1948): Demographic gravitation: evidence and applications. Sociometry, 11(1/2): 31-58.

STOCKTON, J. C., DUKE-WILLIAMS, O., STAMATAKIS, E., MINDELL, J. S., BRUNNER, E. J., SHELTON, N. J. (2016): Development of a novel walkability index for London, United Kingdom: cross-sectional application to the Whitehall II Study. BMC Public Health, 16(1): 416.

ŠAŠEK DIVJAK, M. (2008): Urban planning for the strategic spatial development of Ljubljana. Urbani izziv, 19(1): $133-145$.

TAYLOR， P. J.，OPENSHAW， S. (1975): Distance decay in spatial interactions. In: Taylor [ed.]: Concepts and Techniques in Modern Geography, 2. Norwich, School of Environmental Sciences, University of East Anglia.

TIMMERMANS, H., VAN DER WAERDEN, P., ALVES, M., POLAK, J., ELLIS, S., HARVEY, A. S., KUROSE, S., ZANDEE, R. (2003): Spatial context and the complexity of daily travel patterns: an international comparison. Journal of Transport Geography, 11(1): 37-46.

TIEFELSDORF, M. (2003): Misspecifications in interaction model distance decay relations: A spatial structure effect. Journal of Geographical Systems, 5(1): 25-50.

TIRAN, J. (2016): Measuring urban quality of life: case study of Ljubljana. Acta geographica Slovenica 56(1): 57-73. doi.org/10.3986/AGS.4606.

TIRAN, J., BOLE, D., KUMER, P. (2016): Morfološka tipologija stanovanjskih območij v Ljubljani. Geografski vestnik, 88(1): 37-64.

TOBLER, W. R. (1970): A Computer Movie Simulating Urban Growth in the Detroit Region. Economic Geography, 46(sup1): 234-240.

TRANSPORT FOR LONDON (2015): Assessing transport connectivity in London, 60.

TRIBBY, C. P., MILLER, H. J., BROWN, B. B., WERNER, C. M., SMITH, K. R. (2015): Assessing built environment walkability using activity-space summary measures. Journal of Transport and Land Use, 9(1): 187.

VALE, D. S., PEREIRA, M. (2017): The influence of the impedance function on gravity-based pedestrian accessibility measures: A comparative analysis. Environment and Planning B: Urban Analytics and City Science, 44(4): 740-763.

VALE, D. S., SARAIVA, M., PEREIRA, M. (2015): Active accessibility: A review of operational measures of walking and cycling accessibility. Journal of Transport and Land Use, 9(1): 2019-2035.

VASCONCELOS, A. S., FARIAS, T. L. (2012): Evaluation of urban accessibility indicators based on internal and external environmental costs. Transportation Research Part D: Transport and Environment, 17(6): 433-441.

VISION OF LJUBLJANA 2025 (2019): [online]. [cit. 11.11.2019]. Available at: https://www.ljubljana.si/ en/about-ljubljana/vision-of-ljubljana-2025/

WALK SCORE METHODOLOGY (2019) [online]. [cit. 11.11.2019]. Available at: https://www.walkscore. com/methodology.shtml

WALK21: THE INTERNATIONAL CHARTER FOR WALKING (2019) [online]. [cit. 11.11.2019]. Available at: https://www.walk21.com/charter 
WEINBERGER, R., SWEET, M. (2012): Integrating Walkability into Planning Practice. Transportation Research Record: Journal of the Transportation Research Board, 2322(1): 20-30.

WITTEN, K., EXETER, D., FIELD, A. (2003): The Quality of Urban Environments: Mapping Variation in Access to Community Resources. Urban Studies, 40(1): 161-177.

YANG, Y., DIEZ-ROUX, A. V. (2012): Walking Distance by Trip Purpose and Population Subgroups. American Journal of Preventive Medicine, 43(1): 11-19.
YIGITCANLAR, T., SIPE, N., EVANS, R., PITOT, M. (2007): A GIS-based land use and public transport accessibility indexing model. Australian Planner, (44)3: 30-37.

ŽLENDER, V., WARD THOMPSON, C. (2017): Accessibility and use of peri-urban green space for inner-city dwellers: A comparative study. Landscape and urban planning, 165: 193-205.

\section{Please cite this article as:}

TIRAN. J., LAKNER, M., DROBNE, S. (2019): Modelling walking accessibility: A case study of Ljubljana, Slovenia. Moravian Geographical Reports, 27(4): 194-206. Doi: 10.2478/mgr-2019-0015. 